\title{
Cattle Manure Compost Properties with the Addition of Dead Broiler Carcass as Nitrogen Sources
}

\author{
Nanung Agus Fitriyanto*, Muhammad Kemal Bengawan, Ragil Adi Prasetyo, \\ Zaenal Bachruddin and Yuny Erwanto
}

Faculty of Animal Science, Universitas Gadjah Mada, Jl. Fauna No.3 Bulaksumur, Yogyakarta, 55281, Indonesia. ${ }^{*}$ Corresponding author. Email: nanungagusfitriyanto@ugm.ac.id

\begin{abstract}
During production periods, abundant by-products of the dead bird in broiler industries require an adequate alternative treatment to prevent harmful effects from direct disposal in the open environment. This study evaluates compost's efficiency and physicochemical properties produced from coped dead broiler carcass with cattle manure and rice straw. Four treatments were conducted, which illustrated different proportions of broiler carcasses $0 \%$ (P0), 1\% (P1), $3 \%(\mathrm{P} 2)$, and 5\% (P3) in the cattle manure compost. The physicochemical analysis, including color, odor, texture, moisture content, total organic carbon, total organic $(\mathrm{C})$ matter, total nitrogen $(\mathrm{N})$ content, $\mathrm{C} / \mathrm{N}$ ratio, phosphorus $(\mathrm{P})$, and Potassium (K), were defined in this research. The result of the physicochemical composition on this research has filled up the Indonesian compost standard SNI:19-7030-2004 except in the total N, total P, and C/N ratio content.
\end{abstract}

Keywords: Broiler carcasses, Composting, Physicochemical

\section{INTRODUCTION}

Organic waste produced by livestock includes manure, litter, residual feed, feather, and dead livestock due to illness or other causes. Furthermore, if not handled properly, these organic wastes will cause pollution and environmental hazard in the high-level accumulation of concentrated production and large volumes of waste [1]. The potential to pollute and damage the environment can also make a livestock business unable to run sustainability, such as the difficulty of obtaining a business license from the local government or getting protests from the surrounding community. It is necessary to pay attention to organic waste handling and be more profitable based on this fact. The organic waste can be managed into a product, one example being composted.

Composting is a process of biological decomposition and stabilizing organic substrates so that heat will be produced and a final product that is stable, free of pathogenic bacteria and plant seeds, and can be used as a natural fertilizer. The main ingredients of composting are organic substrates that can be obtained from living things, such as digestive waste products or body parts from living things themselves. Composting is usually done using materials belonging to the organic waste group. Organic waste is considered unused and discarded goods but can still be used if managed with the proper procedures [2].

The local farmer in Indonesia is very common to process the organic livestock waste into compost using the traditional method. However, the organic waste used generally comes from livestock manure, litter, and feed residues, while dead livestock carcasses have not received much attention. The poultry farm has a high risk and potency in the livestock industry to generate high waste in dead livestock carcasses from the population, living periods, and production periods. The poultry industry's mortality rates, especially in Broiler chicken farms in Indonesia, have approximately 4.5$5.5 \%$ per period [3]. The practice of handling dead broilers by farmers in Indonesia is generally limited to burying carcasses and sometimes destroying them by burning them on modern and large-scale farms. Based on this, it is necessary to pay attention to handling dead carcasses, so handling dead broilers by composting might be considered one solution for handling dead livestock waste.

Composting dead chicken with cattle manure was expected to be an innovation that can make it easier for small-scale broiler farms to practice and handle dead 
chicken waste because cattle manure is easier and faster to obtain than poultry litter. An adult cow could produce manure as much as $23.59 \mathrm{~kg} /$ day [4]. Livestock manure can be used as raw material for biofertilizer and organic compost. However, based on some previous research, compost from livestock manure, especially in the Ruminantia, has a low $\mathrm{N}$ content. Thus, it requires other potential ingredients to increase the final $\mathrm{N}$ content in mature compost [5-7]. Broiler chicken as a food source of protein must have a high protein content. The chicken meat has a protein content ranging from $15 \%$ to $25 \%$ [8]. The broiler feathers contain $82.36 \%$ crude protein [9], and the bone filling materials are protein and mineral salts [10]. Broiler carcasses, which are livestock organic wastes with high protein content, also make researchers think that composting broiler carcasses can increase the nitrogen content of the compost that will be produced. Based on this, researchers are interested in researching the proportion of broiler chicken carcasses on beef cattle feces compost. From this research, we expect to provide benefits as an innovation in handling broiler carcasses and reducing environmental pollution due to broiler carcass waste that is not handled correctly. The results of this study can also provide benefits as information material for farmers and the public about the feasibility of using broiler chicken carcasses as raw material for making compost.

\section{MATERIALS AND METHODS}

\subsection{The preparation of materials for composting}

Cattle manure, the dead body of Broiler chicken from a local poultry slaughterhouse, Effective microorganisms (EM4), rice straw, dolomite $\left[(\mathrm{CaMg})_{2} \mathrm{CO}_{3}\right]$, and wood ash were used as research materials. Composting begins with collecting cattle manure from the cattle cage at Meat, Draught, and Companion Animals Laboratory in Animal Science Faculty of Universitas Gadjah Mada. Fresh cattle manure was firstly dried to a water content of $50 \%$ to $60 \%$. The appropriate water content of the feces can be determined by squeezing the feces. If the water does not come out, it means that the water content of the feces is appropriate. This study consisted of 4 treatments, with each treatment having three replications. Each treatment has a difference in the percentage of giving carcasses in the manufacture of $100 \mathrm{~kg}$ of compost, namely $0 \%(\mathrm{P} 0)$, $1 \%(\mathrm{P} 1), 3 \% \quad(\mathrm{P} 2)$, and $5 \%(\mathrm{P} 3)$. The material percentage and the calculation of the composition of the ingredients for composting are shown in Table 1.

The composting process was initially by cutting the straw and dead broiler chicken into smaller sizes and parts $(5-7 \mathrm{~cm})$. The ingredients were then weighed and mixed according to the composition of each treatment, except for the chicken parts. The composting materials were then arranged in a stratified order. Every $15 \mathrm{~cm}$ to $30 \mathrm{~cm}$ of material, the chicken parts were added. The stack of composting material that had been arranged was then covered. The composting process was conducted for five weeks, with each week for turning over. During the composting process, the physical quality of the compost was characterized, including physical changes and $\mathrm{pH}$ of the compost. Measurement of temperature was carried out every day. The chemical quality test of the compost was carried out after five weeks of the composting process.

\subsection{The observation and the measurement of Physico-chemicals quality of compost}

The compost's physical quality observation includes color, odor, texture, temperature, and $\mathrm{pH}$ were measured during the composting process. The compost color, odor, and texture tests were carried out once a week, along with the compost turning time. Measurement of temperature and $\mathrm{pH}$ of compost was carried out using a thermometer and $\mathrm{pH}$ meter. The measurement of the chemical quality test is carried out by taking samples of finished compost from each treatment and replication. The compost sample was then analyzed chemically for moisture, organic carbon, and organic matter using the furnace method. The total nitrogen content was analyzed using the spectrophotometric method. $\mathrm{C} / \mathrm{N}$ ratio, phosphorus content analyzed using the same method, and Kalium content analyzed using the Atomic Absorption Spectrophotometer (AAS) [11].

Table 1. The percentage of materials and the calculation of the composition of the compost ingredients

\begin{tabular}{|l|l|l|l|l|}
\hline \multirow{2}{*}{ Composition } & \multicolumn{3}{|l|}{ The dead body of Broiler chicken addition (\%) } \\
\cline { 2 - 5 } & $\mathrm{P0}(\mathrm{0} \%)$ & $\mathrm{P} 1(\mathrm{1} \%)$ & $\mathrm{P} 2(3 \%)$ & $\mathrm{P3}(5 \%)$ \\
\hline Cattle Manure $(\mathrm{kg})$ & 93.1 & 92.1 & 90.1 & 88.1 \\
\hline Rice Straw $(\mathrm{kg})$ & 6 & 6 & 6 & 6 \\
\hline Dolomite $(\mathrm{CaMg})_{2} \mathrm{CO}_{3}(\mathrm{~kg})$ & 0.3 & 0.3 & 0.3 & 0.3 \\
\hline Wood Ash $(\mathrm{kg})$ & 0.3 & 0.3 & 0.3 & 0.3 \\
\hline Starter (EM4) $(\mathrm{ml})$ & 0.3 & 0.3 & 0.3 & 0.3 \\
\hline The dead body of Broiler chicken $(\mathrm{kg})$ & 0 & 1 & 3 & 5 \\
\hline
\end{tabular}




\subsection{Statistical and analysis data.}

The observation result of physical quality during composting was analyzed in descriptive (figure and graphical). The data for the Physico-chemical quality of compost were analyzed statistically using Completely Randomized Design (One-way ANOVA) and continued

by Duncan's multiple range test (DMRT) if there were differences with significant effect $(\mathrm{P}<0.05))$ among the treatments [12].

\section{RESULTS AND DISCUSSIONS}

\subsection{The observation of physical characters during composting}

Composting is a natural process of organic matter biodegradation by microbes that utilize organic matter as an energy source. Physically, there will be a change in the shape of the composting material, which is an organic material, from solid form to soil or compost. In this study, composting was carried out with three main ingredients of cattle manure, dead broiler chicken carcass, and rice straw. All of the components were classified as organic matter. During the composting process, the three materials that have been mixed and arranged into one will undergo decomposition to become a compost product, which causes physical changes. These physical changes include the color, aroma, and texture of the composting materials. Physical changes in composting materials during the composting process can be seen in Table 2. Physical changes in the composting materials until the end of the process still leave the feathers and bones that are not completely decomposed. Broiler feathers still look natural, although a little brittle (Figure 1). At the end of the composting process, the broiler chicken bones were clean of adhering meat, but only some of the broiler bones were brittle or became slightly tender (Figure 2). This condition is following the statement of the previous study [10]. In composting carcasses, feathers and bones can be left that will not decompose completely, but feathers and bones from the carcass composting process can be used for further composting.

Feathers are an epidermal organ with a keratin arrangement classified as "hard keratins" [13]. These keratins make the hair insoluble in water, weak acid, alkaline, and organic solvents. Hard keratins are also resistant to most degradation processes by proteases. In addition, the main thing that makes the decomposition process of feathers difficult is the lack of keratindegrading microorganisms in the environment. The only way to speed up the decomposition of feathers is by adding particular microorganisms capable of degrading feathers keratin. Besides the feather substrate, the bone was challenging to decompose and can last a long time in the soil because the bone has collagen, rich in glycine and proline, and a unique amino acid composition. The amino acids are hydroxylysine and hydroxyproline. Hydroxyproline stabilizes the three-chained superhelix with hydrogen bonds between the chain bonds, while hydroxylysine is responsible for covalent bonds in the secondary crosslinks of monomers. The bonding chain of bone collagen causes bones to be insoluble in water, very strong, has a stable structure, and because they are packed with bone minerals, bones can last a long time in the soil. Therefore, even fossil bones can still store collagen remnants, even though the fossil bones have undergone diagenesis [14].

Observing physical changes between cattle manure compost and broiler chicken carcass for all treatments $(\mathrm{P} 1, \mathrm{P} 2$, and $\mathrm{P} 3)$ and without broiler chicken carcass (P0) in the first week has shown no difference in the parameters of color and texture. The whole compost is yellowish-brown in color, has a coarse and softly agglomerate texture, and is still lumpy (not loose like soil). There was a difference in odor parameters, in which the compost of cattle manure with broiler chicken carcasses all produces a powerful gas odor. In contrast, in cattle manure compost without broiler chicken carcass, dominated by the only manure odor. The odorous gas smell that arises in the compost with broiler chicken carcasses is like a mixture of several gases. The aroma of the gas can still be smelled until the third week of the composting process. Composting carcasses may produce odorous gas such as $\mathrm{NH}_{3}$ (ammonia), $\mathrm{H}_{2} \mathrm{~S}, \mathrm{CH}_{4}$. Ammonia $\left(\mathrm{NH}_{3}\right)$ has a very unpleasant odor produced from the decomposition of proteins in composting materials. The smell of this gas is very strong because chicken carcasses are composting materials rich in protein [15].

The presence of broiler carcasses in the composting process provides a very significant difference in the observed physical changes of compost compared to compost without broiler carcasses. Observation of the physical changes of the compost in the third week resulted in compost with brownish color, compost starting to crumble, straw texture starting to lose, and starting to smell like soil with a slight smell of unpleasant gas. Furthermore, in the third week, composting dead broiler chicken carcasses with cattle manure caused the compost to have a slight carcass smell. Composting broiler chicken carcasses with beef cattle feces also leaves feathers and bones without any meat in the third week of the composting process. This result is linear with the other previous research, which states that small carcasses such as birds (broiler chickens) and fish that are still in good condition will generally decompose entirely within 2 to 3 weeks [10]. Physical changes in the compost in the fourth week have shown signs of compost starting to mature. This is indicated by the color of the compost that is evenly brownish-black, smells like soil entirely without leaving 
the smell of manure or carcasses has a slightly coarse texture, and is crumbly. According to the standard of SNI:19-7030-2004, the mature compost has a brownishblack color or tends to be black with a texture and smell like soil [16]. The composting process was conducted until the fifth week because the compost pile temperature was higher than the ambient temperature and to find out more about the condition of organic matter, especially broiler chicken carcasses, if composting is carried out until the fifth week. The results of the fifth week of composting showed an insignificant change with the compost condition at the fourth week, and the compost still left feathers and bones from the carcass of broiler chickens. The difference in compost conditions in the fifth week was only seen at the compost temperature, which had a temperature level that was close to the ambient temperature.

Table 2. Observations of changes in color, aroma, and texture of compost for 5 weeks

\begin{tabular}{|c|c|c|c|c|}
\hline \multirow{2}{*}{ Week } & \multirow{2}{*}{ Treatment } & \multicolumn{3}{|l|}{ Parameters } \\
\hline & & Color & Aroma & Texture \\
\hline \multirow{4}{*}{0} & P0 & Brownish-yellow & The pungent smell of cattle manure & Dense, coarse, softly agglomerate \\
\hline & P1 & Brownish-yellow & The mixture of fresh manure and fishy & Dense, coarse, softly agglomerate \\
\hline & $\mathrm{P} 2$ & Brownish-yellow & The mixture of fresh manure and fishy & Dense, coarse, softly agglomerate \\
\hline & P3 & Brownish-yellow & The mixture of fresh manure and fishy & Dense, coarse, softly agglomerate \\
\hline \multirow{4}{*}{1} & PO & Brownish-yellow & The odor like cattle manure & Coarse, soft, and agglomerate \\
\hline & P1 & Brownish-yellow & Strong odorous gas (manure+carcasses) & Coarse, soft, and agglomerate \\
\hline & $\mathrm{P} 2$ & Brownish-yellow & Strong odorous gas (manure+carcasses) & Coarse, soft, and agglomerate \\
\hline & P3 & Brownish & Strong odorous gas (manure+carcasses) & Coarse, soft, and agglomerate \\
\hline \multirow{4}{*}{2} & PO & Brownish & Less smell of manure & Coarse-textured and slightly soft \\
\hline & P1 & Brownish & Strong odorous gas (manure+carcasses) & Coarse-textured and slightly soft \\
\hline & P2 & Brownish & Strong odorous gas (manure+carcasses) & Coarse-textured and slightly soft \\
\hline & P3 & Brownish & Strong odorous gas (manure+carcasses) & Coarse-textured and slightly soft \\
\hline \multirow{4}{*}{3} & PO & Brownish & Less smell of manure & a little crumb texture \\
\hline & P1 & Brownish & Less odorous gas carcasses smell & a little crumb texture \\
\hline & P2 & Brownish & Less odorous gas carcasses smell & a little crumb texture \\
\hline & P3 & Brownish & Less odorous gas carcasses smell & a little crumb texture \\
\hline \multirow{4}{*}{4} & PO & Brownish-black & Smell like soil & a little crumb texture \\
\hline & P1 & Brownish-black & Smell like soil & a little crumb texture \\
\hline & $\mathrm{P} 2$ & Brownish-black & Smell like soil & a little crumb texture \\
\hline & P3 & Brownish-black & Smell like soil & a little crumb texture \\
\hline \multirow{4}{*}{5} & PO & Brownish-black & Smell like soil & Loose like soil \\
\hline & P1 & Brownish-black & Smell like soil & Loose like soil \\
\hline & P2 & Brownish-black & Smell like soil & Loose like soil \\
\hline & P3 & Brownish-black & Smell like soil & Loose like soil \\
\hline
\end{tabular}



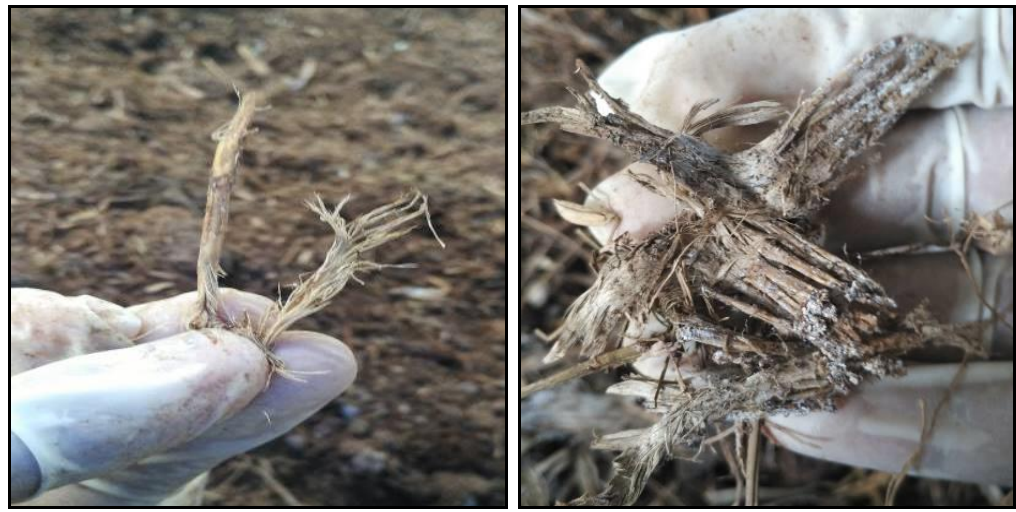

Figure 1. Feathers from the composting process of broiler chicken carcasses
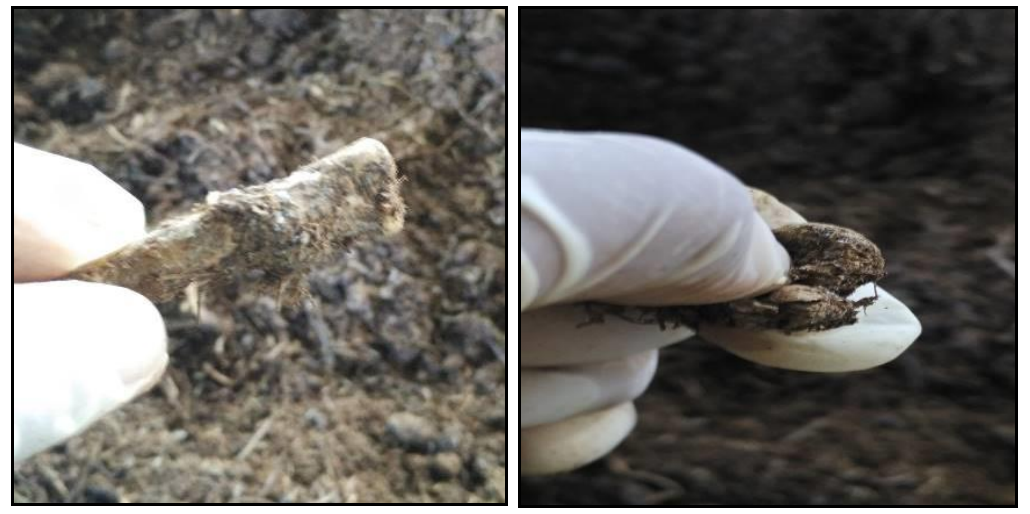

Figure 2. Bone parts left over from the composting process of broiler chicken carcasses

The presence of broiler carcasses in the composting process provides a very significant difference in the observed physical changes of compost compared to compost without broiler carcasses. Observation of the physical changes of the compost in the third week resulted in compost with brownish color, compost starting to crumble, straw texture starting to lose, and starting to smell like soil with a slight smell of unpleasant gas. Furthermore, in the third week, composting dead broiler chicken carcasses with cattle manure caused the compost to have a slight carcass smell. Composting broiler chicken carcasses with beef cattle feces also leaves feathers and bones without any meat in the third week of the composting process. This result is linear with the other previous research, which states that small carcasses such as birds (broiler chickens) and fish that are still in good condition will generally decompose entirely within 2 to 3 weeks [10]. Physical changes in the compost in the fourth week have shown signs of compost starting to mature. This is indicated by the color of the compost that is evenly brownish-black, smells like soil entirely without leaving the smell of manure or carcasses has a slightly coarse texture, and is crumbly. According to the standard of SNI:19-7030-2004, the mature compost has a brownishblack color or tends to be black with a texture and smell like soil [16]. The composting process was conducted until the fifth week because the compost pile temperature was higher than the ambient temperature and to find out more about the condition of organic matter, especially broiler chicken carcasses, if composting is carried out until the fifth week. The results of the fifth week of composting showed an insignificant change with the compost condition at the fourth week, and the compost still left feathers and bones from the carcass of broiler chickens. The difference in compost conditions in the fifth week was only seen at the compost temperature, which had a temperature level that was close to the ambient temperature.

\subsection{The observation of temperature characters during composting}

The results of temperature measurements for compost P0 (compost of beef cattle feces without carcasses), P1 (compost with $1 \%$ broiler chicken carcass), P2 (compost with 3\% broiler chicken carcass), and P3 (compost with 5\% broiler chicken carcass) during the composting process during five weeks can be seen in Figure 3. 


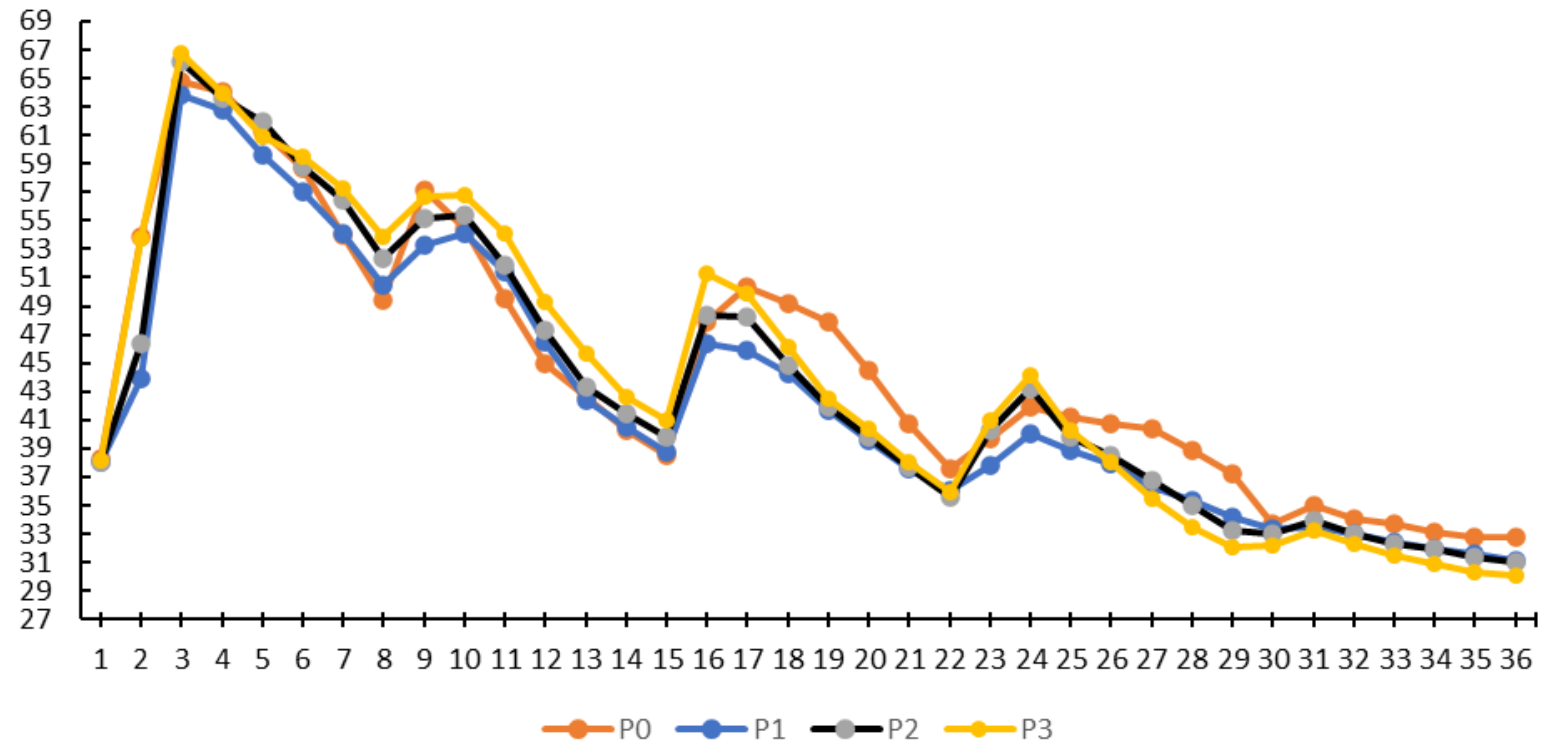

Figure 3. Changes in compost temperature P0, P1, P2, and $\mathrm{P} 3$ during the composting process

The observation data in Figure 3 showed that the compost temperature increases every 2 or 3 days after the compost is turned over, and then the temperature will decrease again. Compost temperature fluctuations were very clearly seen in the second and third weeks, where the temperature returned to a thermophilic condition after experiencing a decrease in temperature. During the composting process of carcasses, the compost temperature usually returns to a thermophilic condition for several weeks [10]. These conditions are perfect for composting carcasses because they can be beneficial in reducing pathogens. At the beginning of the composting process, the intensive microbiological activity caused in the compost increases up to $60^{\circ} \mathrm{C}$ or more. After some time, the temperature decreases again when the composting process goes from decomposition to maturation [17]. Compost piles that begin to experience a decrease in temperature after reaching a thermophilic condition for several days indicate that the compost is nearing the end of the composting process or the compost pile cannot maintain the bacterial population contained in it. A decrease in the compost pile's temperature can also occur due to lack of air, water, or composting feed ingredients that are immediately ready for consumption by composting microorganisms. The active condition of composting can be restored by turning the compost pile and adding sufficient water until the compost pile has the characteristics of mature compost [18].

During the first week, the composting temperature for P0, P1, P2, and P3 increased to reach a peak on the second or third day of composting, which then the temperature will decrease. The highest average temperatures for $\mathrm{P} 0, \mathrm{P} 1, \mathrm{P} 2$, and $\mathrm{P} 3$ during the composting process were $64.82^{\circ} \mathrm{C}, 63.84^{\circ} \mathrm{C}, 66.21^{\circ} \mathrm{C}$, and $66.81^{\circ} \mathrm{C}$, respectively. Compost temperature achievement of P0, P1, P2, and P3 is suitable for killing pathogenic microorganisms in composting materials. The optimal temperature in compost should reach 60 $65^{\circ} \mathrm{C}$ for a better physical quality of the compost. However, a temperature at 70 or $80^{\circ} \mathrm{C}$ is not desirable. This condition happens when the starting mixture is too rich in $\mathrm{N}$, combined with sufficient oxygen and not enough moisture content. A very high temperature in a pile limits the diversity of the microorganisms in the composting material and decreases the decomposition rate. The compost temperature in the last weeks $\left(4^{\text {th }}\right.$ week to $5^{\text {th }}$ week) did not have dramatic fluctuations and decreases, but only a slight temperature change. At the end of the composting process, compost temperatures for $\mathrm{P} 0, \mathrm{P} 1, \mathrm{P} 2$, and $\mathrm{P} 3$ averaged between $29^{\circ} \mathrm{C}$ to $31^{\circ} \mathrm{C}$. The ambient temperature on the last day of composting was recorded at $26^{\circ} \mathrm{C}-29^{\circ} \mathrm{C}$. These conditions indicate that the compost has matured. The compost temperature indicated it is equal to or close to the ambient temperature, and the compost temperature has stabilized. [10] states that when the decomposition process is over, the temperature will slowly decrease until the compost temperature remains in the same temperature range as the ambient temperature.

\subsection{The observation of $\mathrm{pH}$ value during composting}

The results of measuring the $\mathrm{pH}$ value of the compost during the composting process for cattle manure compost without broiler chicken carcasses (P0) and cattle manure compost with the addition of broiler chicken carcasses (P1, P2, and P3) can be seen in Figure 4. Based on the results of observations that have been carried out, it shows that the $\mathrm{pH}$ value of the compost shows a fluctuating value, ranging from 6.5 to 7.5 . This 
condition is linear with the other previous study, which states that the $\mathrm{pH}$ level in the first few days of the composting process can decrease to number 4 due to the formation of organic acids in the composting material [18]. The $\mathrm{pH}$ condition is optimal for composting between 6.5 to 8 degrees of acidity. In most cases, $\mathrm{pH}$ adjustment is not necessary due to the natural buffering capacity of organic matter. In the final week, a higher $\mathrm{pH}$ alkaline occurred in $\mathrm{P} 1, \mathrm{P} 2$, and $\mathrm{P} 3$ compared to $\mathrm{P} 0$ without the carcass addition. These fluctuations of $\mathrm{pH}$ value may be due to increased microbiological activity and the nitrogen cycle during composting. Changes in $\mathrm{pH}$ at the beginning of composting occur due to mineralization. Organic nitrogen is transformed on the ammonium and ammonia through an alkaline reaction, increasing the $\mathrm{pH}$ inside the pile $[19,20]$.

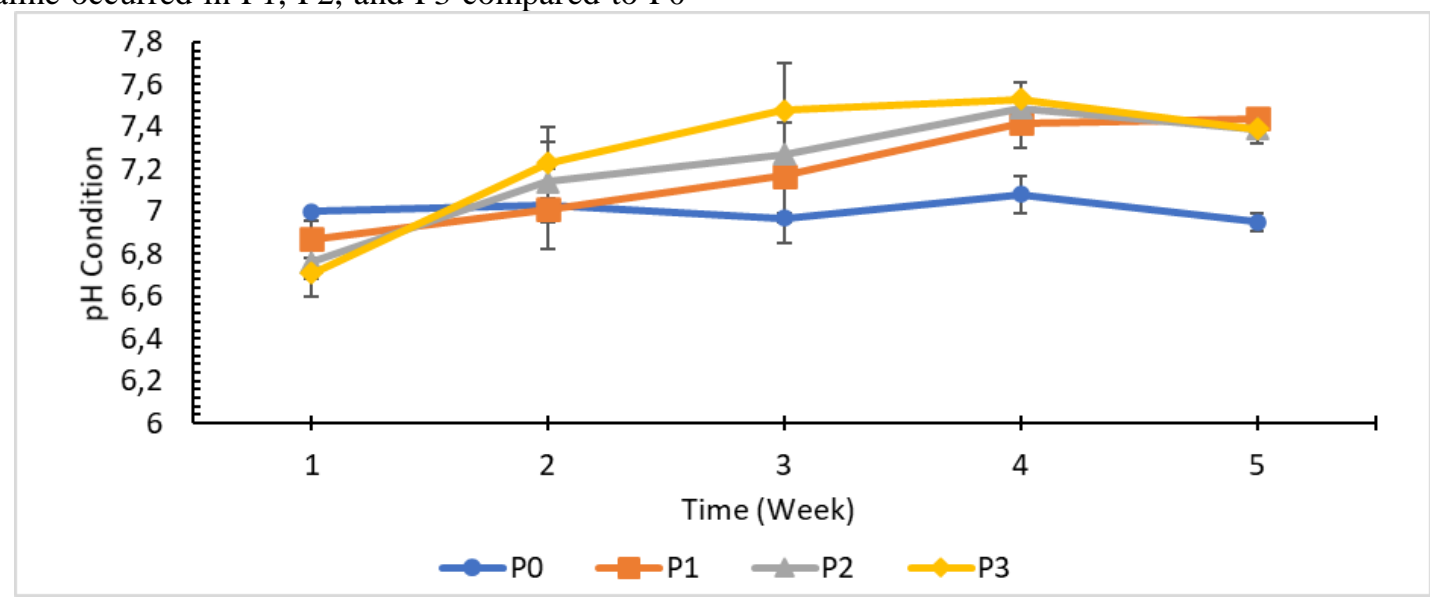

Figure 4. The fluctuation of $\mathrm{pH}$ value of compost during the composting process per week

\subsection{Physicochemical characters after 5 weeks composting}

The organic materials used in composting are beef cattle feces, straw, and broiler chicken carcasses. These organic materials cannot be used directly by the plants, therefore composting is applied. Plants cannot directly utilize that organic matter because the $\mathrm{C} / \mathrm{N}$ content of organic matter does not match the $\mathrm{C} / \mathrm{N}$ content of the soil. Raw animal manure contains higher carbon than nitrogen content. This condition causes livestock manure which is still in the raw condition is used for plant fertilizer. It will invite millions of bacteria to decompose the carbon chain (decomposition), increasing soil temperature so that plants wither or even die from overheating. Compost is organic material that has undergone a decomposition process by decomposing microorganisms, so it can be used to improve soil properties [17]. Some factors interfere in the maturation and quality of the final composting product that can be constantly monitored and evaluated related to the inhibition and development of the microbiological activity, including temperature, $\mathrm{pH}$, aeration, $\mathrm{C} / \mathrm{N}$ ratio, and moisture content $[21,22]$. Based on the results of composting for 5 weeks, it was found that the compost with the Physico-chemical composition is presented in the following Table 3. The physical parameter of compost quality was had no different value $(\mathrm{P}>0,05)$ in the matured compost composition after 5 weeks of incubation except in $\mathrm{pH}$ value. The physical quality in this study is brownish-black in color, the aroma compost like the soil, the texture was loose like soil in all treatment temperature at $30.1-32^{\circ} \mathrm{C}$ and $\mathrm{pH}$ value at $6.95-7.39$. Besides this result, the composition of the matured compost after 5 weeks had different values $(\mathrm{P}<0.05)$ on the chemicals composition at moisture content, total organic matter, total Corganic, total $\mathrm{N}, \mathrm{C} / \mathrm{N}$ ratio, and total $\mathrm{P}$. The result of the physicochemical composition on this research has filled up the Indonesian compost standard SNI:19-7030-2004 except in the total $\mathrm{N}$, total $\mathrm{P}$, and $\mathrm{C} / \mathrm{N}$ ratio content.

The organic matter content analysis results in this study showed that the highest organic matter content value was found in P2 (compost with the addition of $3 \%$ broiler carcasses). In contrast, the compost with the lowest organic matter content was owned by P0 (compost without broiler carcasses). Compost $\mathrm{P} 0$ proved to be significantly different from compost P2 and P3, while compost P1 was shown to be not significantly different from compost $\mathrm{P} 0, \mathrm{P} 2$, and $\mathrm{P} 3$. The organic matter content of compost $\mathrm{P} 0, \mathrm{P} 1, \mathrm{P} 2$, and $\mathrm{P} 3$ followed the Indonesian compost standard SNI:19-7030-2004, where good compost organic matter was between $27 \%$ to $58 \%$. The analysis of organic matter content also showed that the organic matter content of compost with the addition of broiler carcasses (P1, P2, and P3) was higher than compost without broiler carcasses (P0). The organic matter content of compost with broiler chicken carcasses is higher, presumably because broiler chicken carcass is a composting material with a higher organic matter content than beef cattle feces, which is a waste product of metabolism. 
Table 3. Physicochemical composition after 5 weeks of composting

\begin{tabular}{|c|c|c|c|c|c|}
\hline \multirow[b]{2}{*}{ Parameters } & \multicolumn{3}{|l|}{ Treatments } & \multirow[b]{2}{*}{ P3 } & \multirow[b]{2}{*}{$\begin{array}{l}\text { Standar } \\
\text { reference value }{ }^{\star \star}\end{array}$} \\
\hline & PO & P1 & P2 & & \\
\hline Color ns & Brownish black & Brownish black & Brownish black & Brownish black & Brownish black \\
\hline Aromans & Like soil & Like soil & Like soil & Like soil & Like soil \\
\hline Texture ns & Loose like soil & Loose like soil & Loose like soil & Loose like soil & Loose like soil \\
\hline $\mathrm{pH}^{*}$ & $6.95 \pm 0.04^{a}$ & $7.44 \pm 0.02^{c}$ & $7.39 \pm 0.03^{b c}$ & $7.39 \pm 0.07 \mathrm{bc}$ & $6.8-7.49$ \\
\hline Temperature $\left({ }^{\circ} \mathrm{C}\right)^{\text {ns }}$ & $32.8 \pm 1.93$ & $31.2 \pm 0.52$ & $31.0 \pm 0.58$ & $30.1 \pm 0.33$ & 28.9-30.3 \\
\hline Moisture (\%)* & $46.12 \pm 1.87^{b}$ & $36.74 \pm 4.19^{a b}$ & $28.99 \pm 7.68^{a}$ & $31.39 \pm 6.22^{a}$ & Max 50 \\
\hline Organic matter (\%) & $31.74 \pm 1.78^{a}$ & $36.21 \pm 2.69^{a b}$ & $40.76 \pm 2.93^{b}$ & $40.04 \pm 4.53^{b}$ & $27-58$ \\
\hline Total C organic* & $18.41 \pm 1.04^{a}$ & $20.99 \pm 1.56^{a b}$ & $23.64 \pm 1.69^{b}$ & $23.22 \pm 2.63^{b}$ & $9.8-32$ \\
\hline Total N (\%)* & $0.033 \pm 0.002^{b}$ & $0.025 \pm 0.002^{a}$ & $0.027 \pm 0.003^{a}$ & $0.029 \pm 0.002^{\mathrm{ab}}$ & Min 0.4 \\
\hline C/N Ratio* & $539.01 \pm 75.25^{a}$ & $831.08 \pm 44.18^{b}$ & $865.70 \pm 145.99^{b}$ & $810.22 \pm 176.34^{b}$ & $10-20$ \\
\hline Total P $(\%)^{\star}$ & $0.024 \pm 0.001^{b}$ & $0.021 \pm 0.003^{a b}$ & $0.018 \pm 0.003^{a}$ & $0.019 \pm 0.002^{a b}$ & Min 0.1 \\
\hline Total K (\%) ns & $0.40 \pm 0.17$ & $0.33 \pm 0.02$ & $0.38 \pm 0.06$ & $0.38 \pm 0.11$ & Min 0.2 \\
\hline
\end{tabular}

ns : There were no different significant effects $(\mathrm{P}>0.05)$

*: ${ }^{\text {a, b, c, d }}$ means in the same column with different superscript differ significantly effects $(\mathrm{P}<0.05)$

**: Reverence value: SNI:19-7030-2004

Nitrogen is needed for plant growth. Therefore, compost products are expected to have a high enough nitrogen content. The results of the analysis of the nitrogen content of the compost showed that the highest nitrogen content was in P0 (compost without broiler carcasses) while the lowest nitrogen content in compost P1(compost with the addition of $1 \%$ broiler carcasses). Compost P0 proved significantly different from compost P1 and P2, while compost P3 was not significantly different from compost $\mathrm{P} 0, \mathrm{P} 1$, and $\mathrm{P} 2$. Overall, the nitrogen content of the compost produced is less than the provisions of the Indonesian compost standard SNI:19-7030-2004, where the minimum nitrogen content in compost is $0.4 \%$. Total $\mathrm{N}$ content in this result was contra with the previous study[23,24] that the utilization of the swine carcasses could significantly increase the total $\mathrm{N}$ content of matured compost. Low compost nitrogen content was suspected due to the release of volatilization gas during the compost turning process. The nitrogen is lost in ammonia $\left(\mathrm{NH}_{3}\right)$ form during the composting process, which causes the odorous gas from the pile.

Based on the analysis of the $\mathrm{C}$-organic content of the compost, it was found that the highest organic C-content was found in P2 (compost with the addition of 3\% broiler chicken carcass). In contrast, the lowest organic C content was P0 (compost without the addition of broiler chicken carcass). Compost P0 proved significantly different from compost $\mathrm{P} 2$ and $\mathrm{P} 3$, while compost P1 was not significantly different from compost P0, P2, and P3. Carbon is a source of energy for the growth of composting microorganisms. In the aerobic decomposition process, some carbon will be released in $\mathrm{CO}_{2}$, and the rest will be combined with nitrogen in the microbial body [18]. The levels of Corganic compost P0, P1, P2, and P3 were good content following the Indonesian compost standard SNI:19$7030-2004$, where the content is in the range of $9.8 \%$ to $32 \%$.

Knowing the nitrogen and carbon content of the compost is needed to determine the $\mathrm{C} / \mathrm{N}$ ratio of the compost later when compared to the nitrogen content of the compost. The value of the $\mathrm{C} / \mathrm{N}$ ratio was obtained from the division of the compost's $\mathrm{C}$-organic content by the compost's nitrogen content. The analysis of the $\mathrm{C} / \mathrm{N}$ ratio of compost showed that the highest $\mathrm{C} / \mathrm{N}$ ratio was owned by P2 (compost with the addition of $3 \%$ broiler chicken carcasses). In contrast, the lowest compost $\mathrm{C} / \mathrm{N}$ ratio was P0 (compost without addition. broiler chicken carcass). Compost P0 proved to be significantly different from compost P1, P2, and P3. Overall, the C/N ratio of the compost produced exceeds the Indonesian compost standard SNI:19-7030-2004 that the allowable $\mathrm{C} / \mathrm{N}$ ratio of compost ranges from 10 to 20 . The $\mathrm{C} / \mathrm{N}$ ratio is a crucial indicator in compost production both as a start-up and quality parameter. The amendment of a material with a low $\mathrm{C} / \mathrm{N}$ ratio, which has not completed the composting process, can lead to phytotoxicity. It is caused by the conversion of ammonium (in hot and humid conditions) into ammonia, creating a toxic environment for plant growth and resulting in odors.

Similarly, unfinished compost contains unstable, volatile chemicals such as organic acids that are toxic to 
seeds and plants. On the other hand, the amendment of a material with a high $\mathrm{C} / \mathrm{N}$ ratio can lead to a biological block of nitrogen, also known as "nitrogen starvation". It occurs in materials that are far richer in carbon than in nitrogen. When applied to soil, microorganisms quickly use the $\mathrm{C}$ present in the material, increasing $\mathrm{N}$ consumption and exhausting N's reserves [25].

Phosphorus (P) for plants helps stimulate root growth, especially seed roots and young plants. Phosphorus nutrients in fresh organic matter are usually present in complex organic forms, complicated for plants to use directly for growth. After undergoing the composting process, microorganisms will convert nutrient phosphorus into PO42- (P-available), which is easily absorbed by plants [26]. Compost products are expected to have sufficient phosphorus content to help plant growth. The results of the analysis of the phosphorus content of the compost showed that the highest phosphorus content was in P0 (compost without broiler carcasses), while the compost with the lowest phosphorus content was in P2 (compost with the addition of $3 \%$ broiler carcasses). Compost $\mathrm{P} 0$ proved significantly different from compost $\mathrm{P} 2$, while compost P1 and compost P3 were not significantly different from compost P0 and compost P2. Based on the results obtained, none of the sample compost met the standards set by the Indonesian compost standard SNI:19-70302004 that the phosphorus content of the compost was at least $0.1 \%$.

Potassium (K) for plants has the primary function of helping the formation of proteins and carbohydrates. Potassium also plays a role in strengthening the plant body, which causes leaves, flowers, and fruit not to fall quickly. Potassium (K) nutrients in fresh organic matter are usually present in complex organic forms that are difficult to use by the plant. After the composting process takes place, the activity of microorganisms will change the potassium nutrient into the form of $\mathrm{K} 2 \mathrm{O}$ (Kavailable), which is easily absorbed by plants [26]. The four treatments used had no significant effect on the potassium $(\mathrm{K})$ content of the compost. Based on the results obtained, all composts sample has met the standards set by the Indonesian compost standard SNI:19-7030-2004 that potassium (K) content of compost is at least $0.2 \%$.

\section{CONCLUSION}

Based on the research, it can be concluded that during the composting process, compost with broiler chicken carcasses produces very strong and odorous gases from the first week to the second week. Composting broiler carcasses with beef cattle feces removes feathers and bones from broiler chicken carcasses. Compost quality's physical parameter had no significant difference $(\mathrm{P}>0,05)$ from the matured compost composition after 5 weeks of incubation, which were brownish-black in color, odor like the soil, the texture was loose like soil in all treatment, the temperature at $30.1-32^{\circ} \mathrm{C}$ and $\mathrm{pH}$ value at $6.95-7.39$. Besides this result, the composition of the matured compost after 5 weeks had different values $(\mathrm{P}<0.05)$ on the chemicals composition at moisture content, organic matter, total $\mathrm{C}$-organic, total $\mathrm{N}, \mathrm{C} / \mathrm{N}$ ratio, and total $\mathrm{P}$. The result of the physicochemical composition on this research has filled up the Indonesian compost standard SNI:19-7030-2004 except in the total N, total P, and $\mathrm{C} / \mathrm{N}$ ratio content.

\section{REFERENCES}

[1] I.A. Baba, M.T. Banday, H.M. Khan, A.A. Khan, A. Akhand, M. Untoo, Economics of Fermentation of Poultry Farm Waste, Int. J. Curr. Microbiol. Appl. Sci. 7 (2018) 2108-2112. https://doi.org/10.20546/ijcmas.2018.706.250.

[2] H. Health, P. North, Composting Dead Poultry, 8 (2006) 141-146.

[3] M.O.L. DeAraujo, O.H. Nono, A. Keban, Perbandingan kinerja usaha ayam broiler Pola kemitraan dan pola mandiri di Kabupaten Nagekeo (Business performance comparison broiler between partnership and independent pattern in Nagekeo District), J. Peternak. Lahan Kering. 2 (2020) 1201-1208 http://dx.doi.org/10.1016/j.ndteint.2014.07.001\%0 Ahttps://doi.org/10.1016/j.ndteint.2017.12.003\%0 Ahttp://dx.doi.org/10.1016/j.matdes.2017.02.024.

[4] S. Rahayu, D. Purwaningsih, Pujianto, Pemanfaatan Kotoran Ternak Sapi Sebagai Sumber Energi Alternatif Ramah Lingkungan Beserta Aspek Sosio Kulturalnya, Inotek. 13 (2009) 150-160.

[5] N.A. Fitriyanto, D.A. Priyadi, Y. Suranindyah, L.M. Yusiati, Y. Erwanto, N. Kurniawati, A. Pertiwiningrum, Biochemical and physical properties of goat feces liquid biofertilizer fermented with chicken excreta combination and different fermentation condition, in: IOP Conf. Ser. Earth Environ. Sci., IOP Publishing, 2019: p. 12108

[6] M. Innocent, P. Deborah, M.-P. Roy, C. David, Nitrogen value of stockpiled cattle manure for crop production, African J. Agric. Res. 16 (2020) 574 584. https://doi.org/10.5897/ajar2020.14718.

[7] N.A. Fitriyanto, D. Natalia, R.A. Prasetyo, Y. Erwanto, Panjono, N. Ngadiono, Properties of rabbit feces composting using indigenous Alcaligenes sp. LS2T and Arthrobacter sp. LM1KK, IOP Conf. Ser. Earth Environ. Sci. 662 
(2021). https://doi.org/10.1088/1755$1315 / 662 / 1 / 012014$.

[8] C. Castellini, C. Mugnai, A. Dal Bosco, Effect of organic sysytem on broiler carcass and meat quality, Meat Sci. 60 (2002) 219-225. www.elsevier.com/locate/meatsci.

[9] T. Tesfaye, B. Sithole, D. Ramjugernath, V. Chunilall, Valorisation of chicken feathers: Characterisation of chemical properties, Waste Manag. $68 \quad$ (2017) 626-635. https://doi.org/10.1016/j.wasman.2017.06.050.

[10] J. Bonhotal, M. Schwarz, R. Rynk, Composting animal mortalities, Cornell Waste Management Institute, 2014.

[11] AOAC, Official Methods of Analysis of the Association of Official Agricultural Chemists, 18th ed., Washington, USA., 2005. https://doi.org/10.1021/ed043p508.1.

[12] R.G.D. Steel, J.H. Torrie, Prinsip dan prosedur statistika (Terjemahan), PT. Gramedia Pustaka Utama, Jakarta, 1995.

[13] L. Lange, Y. Huang, P.K. Busk, Microbial decomposition of keratin in nature-a new hypothesis of industrial relevance, Appl. Microbiol. Biotechnol. 100 (2016) 2083-2096. https://doi.org/10.1007/s00253-015-7262-1.

[14] A. Balzer, G. Gleixner, G. Grupe, H.L. Schmidt, S. Schramm, S. Turban-Just, In vitro decomposition of bone collagen by soil bacteria: The implications for stable isotope analysis in archaeometry, Archaeometry. $39 \quad$ (1997) 415-429. https://doi.org/10.1111/j.14754754.1997.tb00817.x.

[15] A. Kalbasi, S. Mukhtar, S.E. Hawkins, B.W. Auvermann, Carcass composting for management of farm mortalities: A review, Compost Sci. Util. 13 (2005) 180-193. https://doi.org/10.1080/1065657X.2005.10702239.

[16] Badan Standarisasi Nasional, Spesifikasi kompos dari sampah organik domestik (SNI 19-70302004). Badan Standardisasi Nasional, (2004) 1-10.

[17] A.W.G. van der Wurff, J.G. Fuchs, M. Raviv, A.J. Termorshuizen, Handbook for Composting and Compost Use in Organic Horticulture, Wageningen, 2016. https://doi.org/10.5749/j.ctt1pwt70r.13.

[18] NRCS, Managing for Better Compost, Manure Manag. Technol. Dev. Team. (2007) 8.

[19] T. Nolan, S.M. Troy, M.G. Healy, W. Kwapinski, J.J. Leahy, P.G. Lawlor, Characterization of compost produced from separated pig manure and a variety of bulking agents at low initial $\mathrm{C} / \mathrm{N}$ ratios, Bioresour. Technol. 102 (2011) 7131-7138. https://doi.org/10.1016/j.biortech.2011.04.066.

[20] X. Hao, M.B. Benke, Nitrogen transformation and losses during composting and mitigation strategies, Dyn. Soil, Dyn. Plant. (2008) 10-18.

[21] R.A.. Pedrosa, D.; Farias, T. S.; Pereira, A.; Tarcísio, E.F. Rêgo, Monitoramento Dos Parâmetros Físico-Químicos Na Compostagem De Resíduos Agroindustriais Monitoring of Physical and Chemical Parameters in Agroindustrial Waste Composting, Pesqui. Agrárias e Ambient. 01 (2013) $44-48$. http://periodicoscientificos.ufmt.br/ojs/index.php/n ativa.

[22] A.K. da C. Ferreira, N.D.S. Dias, D.A. da C. Ferreira, F.S. de S. Junior, M.D.S. Leite, V.C.N Porto, C.D.S. Fernandes, B.G. de A. Souza, J.F. da Silva, L.M. de Andrade, Monitoring of Physical Parameters in Organic Waste Composting, J. $\begin{array}{lllll}\text { Agric. } & \text { Sci. } & 10 & \text { (2018) }\end{array}$ https://doi.org/10.5539/jas.v10n7p464.

[23] X.C. Yang, Z.Z. Han, X.Y. Ruan, J. Chai, S.W. Jiang, R. Zheng, Composting swine carcasses with nitrogen transformation microbial strains: Succession of microbial community and nitrogen functional genes, Sci. Total Environ. 688 (2019) $555-566$. https://doi.org/10.1016/j.scitotenv.2019.06.283.

[24] L.L.C. Guidoni, G.A. Martins, M.F. Guevara, J.N. Brandalise, T. Lucia, M.D. Gerber, L.B. Corrêa, É.K. Corrêa, Full-Scale Composting of Different Mixtures with Meal from Dead Pigs: Process Monitoring, Compost Quality and Toxicity, Waste and Biomass Valorization. (2021). https://doi.org/10.1007/s12649-021-01422-0.

[25] K. Azim, B. Soudi, S. Boukhari, C. Perissol, S. Roussos, I. Thami Alami, Composting parameters and compost quality: a literature review, Org. Agric. $\quad 8 \quad$ (2018) 141-158 https://doi.org/10.1007/s13165-017-0180-z.

[26] B.Z. Syafrudin, Pengomposan Limbah Teh Hitam Dengan Penambahan Kotoran Kambing Pada Variasi Yang Berbeda Dengan Menggunakan Starter Em4 (Efective Microorganism-4), TEKNIK. 28 (2007) 125-131. https://ejournal.undip.ac.id/index.php/teknik/article /view/2143. 